\title{
Gross-pathologic and therapeutic implications for uncomplicated white line disease in dairy cows: A case series study
}

\author{
Mohsen Nouri ${ }^{2,}$, Fateme Katouli $^{1}$, Fahime Zibaee ${ }^{1}$, Iradj Nowrouzian ${ }^{2}$, \\ Seyed Mohamad Karbalaee Seyed Javad ${ }^{2}$ \\ ${ }^{1}$ Iranian Arad Pajouh Veterinary University Center, Tehran, Iran \\ ${ }^{2}$ Department of Clinical Sciences, Faculty of Veterinary Medicine, the University of Tehran, Tehran, Iran
}

\section{Email address:}

mnouri2@yahoo.com(M. Nouri)

To cite this article:

Mohsen Nouri, Fateme Katouli, Fahime Zibaee, Iradj Nowrouzian, Seyed Mohamad Karbalaee Seyed Javad. Gross-Pathologic and Therapeutic Implications for Uncomplicated White Line Disease in Dairy Cows: A Case Series Study. Animal and Veterinary Sciences. Vol. 1, No. 5, 2013, pp. 32-35. doi: 10.11648/j.avs.20130105.11

\begin{abstract}
This short communication describes the gross-pathologic and therapeutic implications of uncomplicated white line diseasein one large dairy herd with records of lameness events over a 7 months period in the vicinity of Tehran, Iran.White line lesions were confirmed on 232 of cows with the lameness score of 3 and 4 . The prevalence rate of WL lesions in axial wall at zone 1, apex of toe at zone 1 and abaxial wall at zone 1, 2 and 3 were 53 cases (23.0\%), 44 cases $(19.0 \%)$ and 130 cases $(58.0 \%)$, respectively. Fourteen percent have been trimmed incorrectly and the sole becomes too thin during trimming. Full treatment results achieved in $87.0 \%$ of cases in an average of 28 days.This study showed that laminitis- associated white line disease response well to appropriate therapy and proper trimming can play an important role for lameness prevention strategies in large dairy herds.
\end{abstract}

Keywords: Claw, Lameness, Pathology, White Line Disease, Treatment

\section{Introduction}

Claw lesions are the most important cause of lameness $[1,2]$. White line disease (WLD) is a commonly observed lesion and has frequently been reported as a major cause of lameness $[1,3,4]$. WLD accounts for considerable economic cost due to lose in milk yield $[3,5]$, weight and fertility $[6$, 7] and increases the risk of culling [7-9].

Several reports from Iran indicated the condition as responsible for between $1.53 \%$ and $27.14 \%$ of lameness[9-11]. Other studies also have reported the disease between $5.5 \%$ and $39.0 \%$ [1, 4, 12-14]. Nouriet al., (2013) observed affected digits of the culled lame cows with WLD depicted a quite wide range of pathologicsigns such as excessive new bone formation, osteolysis, ankylosis and sequestration of the third phalanx (P3)[7]. Mansouri et al. (2011) found sub-solar abscess in zone 3 progressed to the septic osteitis of the $\mathrm{P} 3$ bone with osseous sequestration in $14.2 \%$ cases[11].In 14 (18.3\%) of 76 cows referred for digit amputation, the primary lesion had been WLD[15]. A prompt identification of problematic cases is needed to be done for prevention of premature culling[7, 9].This short communicationdescribes the gross-pathologic and therapeutic implications of uncomplicated WLD in one large dairy herd with records of lameness events over a 7 months period in the vicinity of Tehran, Iran.

\section{Case History}

Between January and July 2011, 232 Holstein cows having WLDwere treated and the healing process was observed in the course of veterinary practice. The practice is located in a commercial dairy farm with 2800 milking cows in the vicinity of Tehran. The cows were attended at the request of a farmer and the details of each casewere recorded on a prepared lameness form at completion of the farm visit.Cows were kept in free stall with sand beddingon concrete floor and fed a total-mixed ration. The diet consisted of alfalfa hay, corn silage and a commercial concentrate. The mean age of the animals was 3 to 10 years.

All cows were scored for locomotion once a month after milking when leaving the parlour. The locomotion scoring 
system, as developed by sprecher et al., (1997) using a 1 to 5 score, was employed [16].The animals were examined in a claw trimming box and the affected limbs were raised and the claws were trimmed in accordance with the principle of therapeutic foot care[1]. For the purpose of recording distribution of claw lesions on the solar surface, each claw was divided into 6 zones according to an established protocol (Fig. 1)[17].The criteria such as hemorrhage, separation and abscess at white line region in zone 1,2 and 3 served as a basis for the diagnosis.

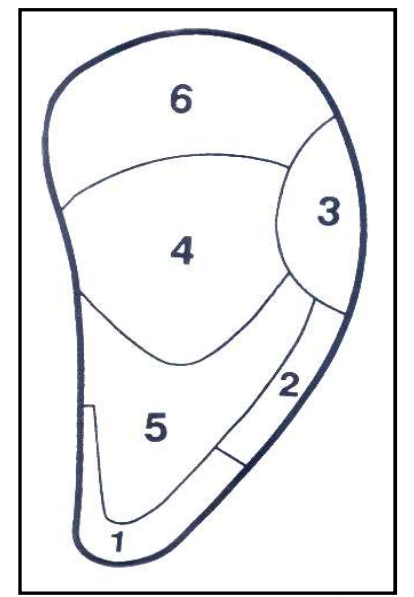

Figure 1: The weight bearing surface of each claw is divided into the following zones: 1 White zone at the toe, 2 Abaxial white zone, 3 Abaxial wall-bulb junction, 4 Sole-bulb junction, 5 Apex of the sole, 6 Bulb of the heel. Zones of sole conform with recommendations established at the 6th Symposium on Diseases of the Ruminant Digit, Liverpool, 1990. Vet Rec., $1991 ; 128: 12$.

The lesions open with a hoof-knife to drain the underlying infection and pared of the loose horn that constitutes the white line, using a sharp hoof knife.Necrotic tissue and granulation tissue were thoroughly removed from the entire claw lesions and the margins of the lesions in animals equal with surface of the corium and either a wooden block fixed to the sound claw in cases the corium has been exposed, and where the animal has to remain in the herd. Any debris or foreign material removed from the depth of the widened separation.A topical ointment (SolkaHoofgel ${ }^{\circledR}$, Kanters Special Products BV, Netherlands) applied to accelerate healing. Systemic antibiotics consisted of the intramuscular administration of oxytetracycline hydrochloride LA (2-5 $\mathrm{mg} / \mathrm{kg}$ ) at seven-day intervals for two weeks.

\section{Results and Discussion}

WL lesions were confirmed on 232 of cows with the score of 3 and 4 . The prevalence rate of WL lesions inaxial wall at zone 1 , apex of toe at zone 1 and abaxial wall at zone 1, 2 and 3 were 53 Cases (23.0\%), 44 Cases (19.0\%) and 130 Cases $(58.0 \%)$, respectively (Fig. 2A, B).Fourteen percent have been trimmed incorrectly; the sole becomes too thin during trimming and exposed corium (Fig. 2A). Full treatment results achieved in $87.0 \%$ of cases in an average of 28 days. Hashemi et al., (2005) observed 56.2 \% of WLD cases have been associated with bone changes of P3, decreased locomotion scoring in an average of 17 days. They foundbone changes of P3 have any effect in treatment of WLD cases. ${ }^{5}$

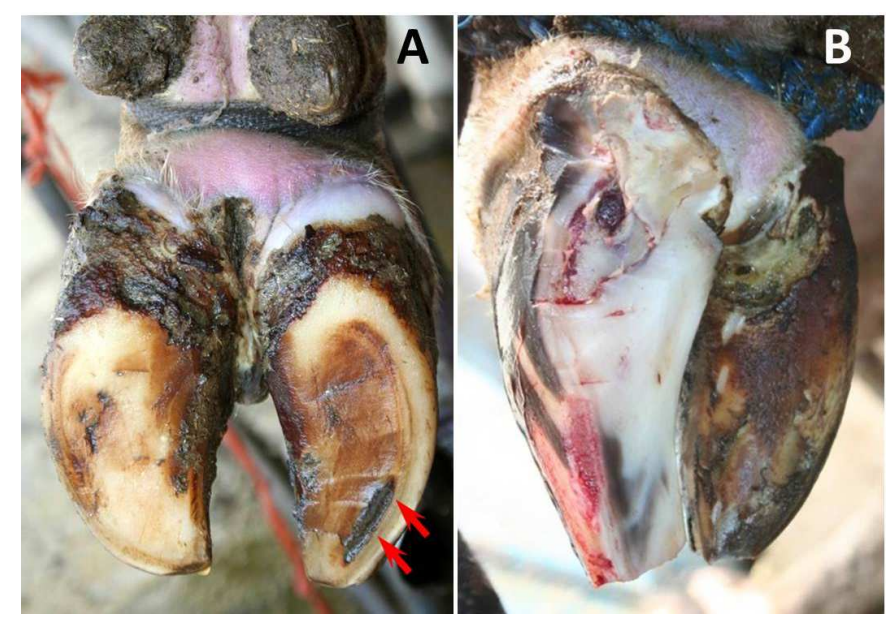

Figure 2: A: Improper hoof trimming techniques resulted in traumatic laminitis; the sole became too thin during trimming in zone 1 and 2(red arrows). B: This is the appearance of an affected claw with WLD 3 that has been severely destroyed. This lesion exposed after careful paring and excavates a small black area in the white line 3.

Complete recovery was achieved in $87.0 \%$ of cases following therapeutic intervention. In cases of deep sepsis of the digit, antimicrobial therapy alone does not usually elicit a cure[18]. It is possible that necrosis of infected tissue and the resultant loss of blood supply prevent effective concentrations of antimicrobials from reaching all areas of bacterial colonization[19, 20]. Another possible explanation is that the anatomical changes of infected or non-infected tissue can be effective on locomotion score. Anatomical changes of P3 bone such as excessive new bone formation, osteolysis, ankylosis and sequestration has been reported by others[5, 7, 9, 11].On the other hand, complication by secondary infections can effect on healing process. Thus, digital amputation or digital salvage procedures involving debridement, drainage and lavage of infected structures is usually required for resolution of lameness[20-22].

White line abscesses occurring towards the zone 3 are more likely to under-run the entire sole. Claw examination involves careful paring to expose and excavate any small black areas in the white line that could mask the site of an abscess (Fig. 2B). In the author's experience, penetration in the zone 3 is easily missed. Percussion of the zone 3 bythe haft of the hoof knife is helpful in locating regions of pain.

The colors of the pus escaping from wound were cream $(14.0 \%)$ and black $(43.5 \%)$. Anecdotally, the color of the pus produced is an indicator to differentiate a lesion caused by external trauma from one caused as the result of the collapse of the pedal bone support system (cream if internal pressures and black if from external entry) [23].

In a proportion of cases lameness did not resolve following drainage of the white line abscess and 
re-examination of the foot revealed a protrusion of granulation tissue from the original lesion. This is often an indication that not all of the under-run horn was removed at the first examination[1, 24].Foreign bodies and secondary infection such as the infectious agents of bovine digital dermatitis (BDD) can effect on healing process. Recently, there have been a number of reports of 'new' disorders affecting the bovine digit. All studies suggested the potential involvement of BDD [25-27].

It is important to minimize wet and unhygienic conditions. Trim the claws regularly to prevent overgrowth, but avoid over-trimming. Improper hoof trimming techniques may result in traumatic laminitis [28]; at least if the trimmer takes away supportive mechanism of the horn with a grinder or the sole becomes too thin during trimming [4](Fig. 2A).Improve walkways to gateways, and areas of congestion. Repair or replace damaged or broken concrete surfaces. Any kind of solid floor will give uniform support to the weight-bearing system of the claw and cause less stress than slatted floors[29]. In addition to an even floor, straw bedding and rubber mats seem to prevent problems [30-31].Biotin is known to increase the rate of healing and to reduce the occurrence of white line lesions $[13,32]$.

\section{Conclusion}

This study showed that laminitis- associated white line disease response well to appropriate therapy and proper trimming can play an important role for lameness prevention strategies in large dairy herds.

\section{References}

[1] Collick DW, Weaver AD, Greenough PR.Interdigital space and claw, In: Greenough PR, Weaver AD, Eds. Lameness in Cattle. $3^{\text {nd }}$ ed. Philadelphia: WB Saunders 1997; 101-7.

[2] Hernandez J, Shearer JK, Webb DW. Effect of lameness on the calving-to-conception interval in dairy cows. J Am Vet Med Assoc 2001;218(10): 1611-1614.

[3] Amory JR, Barker ZE, Wright JL, et al. Associations between sole ulcer, white line disease and digital dermatitis and the milk yield of 1824 dairy cows on 30 dairy cow farms in England and Wales from February 2003-November 2004. Prev Vet Med 2008; 83(3-4): 381- 391.

[4] Kujala M, Dohoo IR, Soveri T. White-line disease and haemorrhages in hooves of Finnish dairy cattle, Prev Vet Med 2010;94(1-2): 18-27.

[5] Hashemi M, Nowrouzian I, Veshkini A. Treatment of white line disease in dairy cattle: Radiographic evaluation, In Proceeding: $4^{\text {th }}$ Convention of Iranian Veterinary Clinicians, Urmia, Iran, 2005; 210 (in Farsi).

[6] Garbarino EJ, Hernandez JA, Shearer JK, et al. Effect of lameness on ovarian activity in postpartum Holstein cows, J Dairy Sci 2004; 87(12):4123-4131.

[7] Nouri M, Nowrouzian I, Marjanmehr SH, et al. Pathomorphologicalfindings of white line disease with digital and inner organ infections in culling dairy cows, Am J Anim Vet Sci 2013; 8(3):122-127.

[8] Cramer G, Lissemore K, Kelton D, et al. The association between hoof lesion and culling risk in Ontario dairy cows. In Proceedings: American Association of Bovine Practitioner, USA, 2006; 39:242-243.

[9] Nouri M, Nowrouzian I, Vajhi A, et al. Morphometric radiographicfindings of the digital region in culling lame cows, Asian J AnimSci 2011;5(4):256-267.

[10] Meimandi-Parizi A, Eskandari A. Prevalence of lameness in dairy and beef cattle of Marvdasht area during the winter, Pajouhesh\&Sazandegi 1996; 35:115-119 (in Farsi).

[11] Mansouri-Nejad SE,AhmadpanahA, KatouliF, et al. A case series study of white line disease in dairy cows: complication and consequences, In Proceeding: $16^{\text {th }}$ International Symposium on Lameness in Ruminants, Rotorua, New Zealand, 2011; 158.

[12] Eddy RG, Scott CP. Some Observation on the incidence of lameness in dairy cattle in Somerset. Vet Rec 1980; 106(7): 140-144.

[13] Hedges V, Blowey RW, Packington AJ, et al. A longitudinal field trial of the effect of biotin supplementation on lameness in dairy cows. J. Dairy Sci 2001; 84(9):1969-1975.

[14] Sogstad AM, Fjeldaas T, Osteras O, ForshellKP.Prevalence of claw lesions in Norwegian dairy cattle housed in tie stalls and free stalls. Prev. Vet. Med. 2005; 70 (3-4): 191-209.

[15] Edwards GB, White line disease of the foot in cattle. Vet Annu 1980; 20:227-232.

[16] Sprecher DE, Hostetler DE, Kaneene JB. A lameness scoring system that uses posture and gate to predict dairy cattle reproductive performance. Theriogen 1997; 47(6):1178-1187.

[17] Greenough PR, Vermunt J. Evaluation of subclinical laminitis in a dairy herd and observations on associated nutritional and management factors. Vet Rec1991;128 (1):11-17.

[18] Van Meter DC, Wenz JR, Garry BF. Lameness in cattle: Rules of thumb. In Proceedings: American Association of Bovine Practitioner, 2005; 38: 40-43.

[19] Trent AM. Treatment of bone and joint infections, In Proceedings: $8^{\text {th }}$ International Symposium on lameness in Ruminants, Banff, Canada, 1994; 72-79.

[20] Ferguson JG. Surgery of the distal limb. In: Greenough PR, Weaver AD, Eds. Lameness in cattle. $3^{\text {nd }}$ ed. Philadelphia: WB Saunders 1997; 248-261.

[21] Starke A, Heppelmann M, Beyerbach M, Rehage J. Septic arthritis of the DIJ in cattle: comparison of joint resection by solar approach and digital amputation. Vet Surg 2007; 36(4): 350-359.

[22] Heppelmann M, Kofler J, Meyer H, et al. Advances in surgical treatment of septic arthritis of the distal interphalangeal joint in cattle: A review, Vet J 2009; 182(2): 162-175.

[23] Greenough PR.Bovine laminitis and lameness, A Hands-On Approach. Elsevier Ltd., Philadelphia PA:Saunders 2007; 225. 
[24] Blowy R. Diseases of the bovine digit, Part 1: Description of common lesions, In Pract 1992; 14(2): 85-90.

[25] Cook N and Burgi K. 'Hairy attack': a new lesion affecting the corium of the white line - a case report. In Proceeding: $15^{\text {th }}$ International Symposium on Lameness in Ruminant. Finland, 2008; 214.

[26] Holzhauer M,Vos J. Non-Healing white line disorders, a new clinical presentation. In Proceeding: $15^{\text {th }}$ International symposium on Lameness in Ruminants, Finland, 2008; 206.

[27] Nouri M and AshrafiHelan J, Clinical and gross pathologic findings of complicated vertical fissures with digital dermatitis in a dairy herd, Vet Res Forum 2012; 3(4): 291-295.

[28] Enevoldsen C, Grohn Y,Thysen T. Heel erosion and other interdigital disorders in dairy cows: Associations with season, cow characteristics, disease, and production. J Dairy Sci 1991;
74(4):1299-1309.

[29] Hinterhofer C, Ferguson, JC, Apprich V, et al. Slatted floors and solid floors: stress and strain on the bovine hoof capsule analyzed in finite element analysis. J Dairy Sci 2006; 89(1): $155-162$.

[30] Kujala M, Dohoo IR, Laakso M, et al. Sole ulcers in Finnish dairy cattle. Prev Vet Med 2009; 89(3-4): 227-236.

[31] Somers JG, Frankena K, Noordhuizen-Stassen EN, Metz JH Prevalence of claw disorders in Dutch dairy cows exposed to several floor systems. J Dairy Sci. 2003; 86(6): 2082-2093.

[32] Pötzsch CJ, Collis VJ, Blowey RW, Packington AJ, and Green LE. The impact of parity and duration of biotin supplementation on white line disease lameness in dairy cattle, J Dairy Sci 2003; 86(8):2577-2582. 